\title{
IMPLEMENTASI METODE TEMATIK DALAM PEMBELAJARAN PENDIDIKAN AGAMA ISLAM PADA ANAK TUNAGRAHITA DI SEKOLAH MENENGAH PERTAMA LUAR BIASA (SMPLB) NGASEM KABUPATEN KEDIRI
}

\author{
Ubet Nashrul Kamal \\ Program Pendidikan Agama Islam Pascasarjana IAIT Kediri \\ ubetnkamal@gmail.com \\ Syafik Ubaidila \\ Institut Agama Islam Tribakti Kediri \\ safik@yahoo.com
}

\begin{abstract}
Abstrak.
Penelitian ini dibingkai dalam topik besar implementasi metode tematik pada anak tunagrahita yang secara khusus melihat praktek pendidikan di sekolah menengah pertama luar biasa ngasem kabupaten Kediri dari keterkaitan antara pembelajaran tematik yang diterapkan oleh guru pada anak tunagrahita dengan hasil dari proses pembelajaran anak tunagrahita dengan metode tematik di Sekolah Menengah Pertama Luar Biasa (SMPLB) Ngasem Kabupaten Kediri. Permasalahan yang diajukan dalam penelitian ini meliputi: 1) Pelaksanaan metode tematik dalam pembelajaran pendidikan agama Islam pada siswa tunagrahita di Sekolah Menengah Pertama Luar Biasa (SMPLB) Ngasem kabupaten Kediri, 2) Hasil pembelajaran metode tematik dalam pembelajaran pendidikan agama Islam pada siswa tunagrahita di Sekolah Menengah Pertama Luar Biasa (SMPLB) Ngasem kabupaten Kediri. Jenis pendekatan penelitian ini adalah kualitatif, sebagaimana arahan jenis penelitian kualitatif, maka data terkumpul dianalisis dengan bekal senjata intelektual berupa teori sebagaimana ditampilkan dalam Bab II untuk mendapatkan berbagai uraian interpretatif sesuai kaidah penelitian ilmiah yang logis dan rasional atas data yang dikumpulkan. Akhirnya, penelitian ini berhasil memperoleh hasil temuan sesuai pertanyaan permasalahan yang pada garis besarnya dapat disimpulkan sebagai berikut. 1) Pembelajaran tematik dalam pelajaran pendidikan agama Islam pada anak tunagrahita relatif baik. 2) hasil dari dari model pembelajaran tematik pada anak tunagrahita dalam pelajaran pendidikan agama Islam dapat disimpulkan relatif baik dan mereka merasa lebih mudah memahami pelajaran pendidikan agama Islam.
\end{abstract}

Kata Kunci : Metode Tematik, Pendidikan Agama Islam, Anak Tunagrahita

\section{Konteks Penelitian}

Pembelajaran tematik merupakan model pembelajaran terpadu yang menggunakan pendekatan tema tertentu yang mencakup beberapa mata pelajaran untuk memberikan pengalaman bermakna kepada siswa. Dalam hal ini, bermakna maksudnya yaitu siswa akan memahami konsep-konsep yang mereka pelajari melalui pengalaman langsung danmengkaitkannya dengan konsep lain yang telah dipahami sebelumnya. Dalam pelaksanaannya, pembelajaran tematik berawal dari suatu tema yang dipilih

1 Trianto, 2012, Mendesain Model Pembelajaran Inovatif - Progresif: Konsep, Landasan, dan Implementasinya pada Kurikulum Tingkat Satuan dan dikembangkan oleh guru dan diaplikasikan pada siswa dengan memperhatikan keterkaitannya dengan isi mata pelajaran.

Dalam implementasi model pembelajaran pada mata pelajaran Pendidikan Agama Islam tidak bisa terlepas dari dua komponen lainnyayaitu metode dan media pembelajaran. Karena komponenkomponen pembelajar an ini saling berkaitan dan melengkapi. ${ }^{1}$

Pada pembelajaran tematik, siswa tidak perlu mengetahui pergantian mata

Pendidikan (KTSP), Kencana Prenada Media Group, Jakarta., hal.25 
pelajaran satu ke mata pelajaran yang lain, karena berbasis pada satu tema dan perpindahan dari mata pelajaran satu dengan yang lain dikemas agar siswa tidak terasa pada setiap perpindahan mata pelajaran. Selain itu, dalam pembelajaran tematik juga ditandai dengan keaktifan siswa dalam mengikuti pembelajaran. ${ }^{2}$

Kebutuhan tiap murid disekolah luar biasa tentu tidak semua sama, oleh karena itu kebebasan bagi guru untuk dapat mengembangkan ide-ide maupun pemikiran yang kreatif sangat dibutuhkan, akan tetapi masih banyak pelaksanaan pendidikan disekolah luar biasa yang belum sesuai dengan apa yang telah ditetapkan oleh pemerintah. Pendidikan bagi anak berkelainan masih sering termarjinalkan, khususnya bagi siswa tunagrahita.

Anak tunagrahita merupakan salah satu klasifikasi Anak Berkebutuhan Khusus (ABK) dengan hambatan dibidang mental. Hambatan mental yang dialami anak tunagrahita sering membuat mereka tidak dapat mengolah informasi yang diperoleh sehingga tidak dapat mengikuti perintah dengan baik. Anak tunagrahita memiliki kemampuan akademis dibawah rata-rata yang menyebabkan mereka tidak dapat berkembang sesuai dengan tahapan perkembangan pada usianya selayaknya anak-anak normal.

Hambatan intelektual yang dialami oleh anak tunagrahita menyebabkan perasaaan frustasi sehingga perkembangan emosi mereka menjadi ikut terhambat. Emosi pada anak tunagrahita sering tidak terkontrol dan meledak ledak. Dalam beberapa kasus anak tunagrahita ada yang terlalu agresif adapula yang sangat tertutup, emosi yang kompleks inilah yang menyebabkan mereka kesulitan dalam bersosialisasi dengan orang lain. Berdasarkan hambatan-hambatan yang dialami oleh anak tunagrahita, pembelajaran yang diterapkan tidak dapat disamakan dengan anak normal pada umumnya. Dalam menentukan strategi yang efektif guru harus memperhatikan tujuan pelaksanaan

2 Trianto, Model-Model Pembelajaran Inovatif Berorientasi Kontruktivistik (Jakarta: Prestasi Pustaka, 2007), 13. pembelajaran, karakteristik dari anak tunagrahita, dan ketersediaan sumber (sarana dan prasarana). Strategi yang dapat digunakan untuk pembelajaran bagi anak tunagrahita adalah strategi yang diindividualisasikan, kooperatif, dan modifikasi tingkah laku. Pendekatan pembelajaran bagi anak tunagrahita juga memerlukan berbagai pertimbangan berdasarkan karakteristik dari anak tersebut. Pendekatan yang cenderung digunakan dalam pembelajaran bagi anak tunagrahita adalah dengan pendekatan modifikasi tingkah laku. Hal ini dikarenakan perkembangan tingkah laku pada anak tunagrahita banyak mengalami hambatan, sehingga tingkah laku yang dikembangkan harus dapat diukur dan diamati. ${ }^{3}$

Hal inilah yang menyebabkan anak tunagrahita memerlukan perhatian yang lebih dibandingkan dengan anak normal pada umumnya. Diperlukan bimbingan dan perhatian guru atau pembimbing agar tingkat perkembangan diri anak yang bersangkutan dapat tercapai sesuai dengan keberadaannya. Hambatan intelektual pada anak tunagrahita tentu sangat berpengaruh pada kemampuan akedemiknya. Anak tunagrahita tidak dapat disamakan kemampuannya dengan anak seusianya dan di sekolah ini guru menggunakan metode pembelajaran tematik yang dianggap cocok untuk memahamkan siswa tunagrahita.

Pembelajaran tematik dapat diartikan sebagai suatu pembelajaran dengan mengintegrasikan materi beberapa mata pelajaran dalam satu tema/topik pembahasan. Disamping itu, pembelajaran tematik akan memberi peluang pembelajaran terpadu yang lebih menekankan pada partisipasi atau keterlibatan peserta didik dalam belajar. Dasar menerapkan dan melaksanakan pembelajaran tematik, ada beberapa prinsip dasar yang perlu diperhatikan yaitu: 1) bersifat terintegrasi dengan lingkungan, 2) bentuk belajar dirancang agar peserta didik menemukan tema, dan 3) efisiensi waktu, beban materi,

3 Adam pranowo dan Qari"ah Hamid. (2012). Teknik Mendongkrak kemampuan anak dengan kecerdasan dibawah rata-rata. Yogyakarta: Familia, hal. 88 
metode, dan penggunaan sumber belajar yang otentik. ${ }^{4}$

Beberapa masalah bisa timbul dalam praktek implementasi model pembelajaran tertentu, seperti dari segi fasilitas sekolah, kondisi peserta didik, dan pemahaman serta penguasaan pendidik terhadap model pembelajaran tertentu. Terkadang guru kurang menguasainya, terlebih model dan metode pembelajaran itu diimplementasikan pada siswa berkebutuhan khusus. Tentu hal ini akan berbeda dengan anak biasa.

Khususnya dalam pembelajaran Pendidikan Agama Islam, agar peserta didik dapat memahami materi yang disampaikan Guru/pendidik dengan baik, maka proses pembelajaran kontekstual, pendidik akan memulai membuka pelajaran dengan menyampaikan kata kunci, tujuan yang ingin dicapai, baru memaparkan isi dan mengakhiri dengan menyimpulkan dan memberikan persoalan kepada peserta didik untuk dibahas di pertemuan yang selanjutnya. ${ }^{5}$

Menerima keragaman manusia dan kebutuhan belajar mereka akan mengarah pada praktek pengajaran yang lebih baik, dengan penggunaan teknik-teknik manajemen kelas yang baru. Anak tunagrahita juga memiliki hak yang sama seperti anak normal lainnya. Mereka menginginkan kesempatan untuk menggali potensi-potensinya guna meraih impian dan cita-cita di masa depannya. Setiap muslim tidak terkecuali memiliki kewajiban yang sama untuk memperoleh pengetahuan dan tidak mempersulitnya. ${ }^{6}$

Pendidikan Agama Islam pada Anak tunagrahita di Sekolah Menengah Pertama Luar Biasa Kabupaten Kediri di daerah Ngasem menarik untuk diteliti dikarenakan beberapa daya tarik yang membuat peneliti mengambil objek tersebut salah satunya yaitu penerapan pembelajaran pendidikan agama Islam dengan metode tematik pada

4 Sungkono, Pembelajaran Tematik dan Implementasinya di Sekolah Dasar.Jurnal Majalah Ilmiah Pembelajaran. Vol. 2, No. 1.2006,hal. 52

5 Ahmad Sudrajad, Pendekatan Ilmiyah/Saintifik dalam proses Pembelajaran, dalam proses

pembelajaran,http://akhmadsudrajad.wordpress.com anak tunagrahita. Sekolah ini baru resmi didirikan pada tahun 2005. Namun, untuk fasilitas, kurikulum ataupun yang lainnya sudah tertata dengan baik. Salah satunya sekolah ini sudah bisa mempersiapkan peserta didik bersaing dengan sekolah umum dalam era kurikulum 2013. Selain itu sekolah yang sudah berdiri selama tiga belas tahun ini juga sudah memperoleh beberapa penghargaan atas beberapa prestasi yang sudah dicapai diberbagai bidang dan yang paling menarik untuk diteliti adalah proses pembelajaran agama Islam pada anak tunagrahita di sekolah ini.

Berdasarkan potret permasalahan yang terjadi di Sekolah Luar Biasa tersebut, sekiranya perlu diadakan penelitian untuk mengetahui penerapan pembelajaran tematik di salah satu sekolah luar biasa. Oleh karena itu, peneliti ingin mengetahui bagaimana implementasi pembelajaran tematik di SMPLB (Sekolah Menengah Pertama Luar Biasa) Ngasem kabupaten Kediri yang menerapkan model pembelajaran pendidikan agama Islam dengan metode tematik.

Melihat hambatan, problematika, serta pemaparan diatas tentang pendidikan dan proses pembelajaran siswa tunagrahita, maka peneliti tertarik untuk meneliti dan mengetahui lebih lanjut mengenai bagaimana pelaksanaan pembelajaran bagi siswa tunagrahita di Sekolsh Menengah Pertama (SMPLB) Ngasem dengan judul "Implementasi Metode Tematik Dalam Pembelajaran Pendidikan Agama Islam Pada Anak Tunagrahita di Sekolah Menengah Pertama Luar Biasa (SMPLB)Ngasem Kabupaten Kediri".

Metode Tematik Dalam Pembelajaran Pendidikan Agama Islam pada Siswa Tunagrahita yang meliputi :

1. Pelaksanaan metode tematik dalam pembelajaran pendidikan agama Islam pada siswa tunagrahita di Sekolah

2013/07/18/pendekatan-saintifikilmiah-dalamprosespembelajaran/, diakses pada 10 Februari 2018, jam 17.18.

6 Hafidz,Muhammad \& Kastolani, 2009, Pendidikan Islam Antar Tradisi dan Modernitas, STAIN Salatiga Press, Salatiga., hal. 141 
Menengah Pertama Luar Biasa (SMPLB) Ngasem kabupaten Kediri.

2. Hasil pembelajaran metode tematik dalam pembelajaran pendidikan agama Islam pada siswa tunagrahita di Sekolah Menengah Pertama Luar Biasa (SMPLB) Ngasem kabupaten Kediri.

\section{Kajian Pustaka \\ Pembelajaran Tematik}

Secara sedarhana apa yang dimaksudkan dengan pembelajaran tematik adalah kegiatan siswa bagaimana seorang siswa secara individual atau secara kelompok dapat menemukan keilmuan yang holistik. ${ }^{7}$

Hal ini sejalan dengan pendapat Sutirjo dan Sri Istuti yang menjelaskan bahwa pembelajaran tematik adalah suatu strategi pembelajaran yang melibatkan beberapa materi pelajaran untuk memberikan pengalaman bermakna kepada peserta didik. $^{8}$

Untuk mengetahui lebih jelas apa itu pembelajaran tematik maka berikut ciri-ciri dari pembelajaran tematik:

"Berpusat pada peserta didik, memberikan pengalaman langsung kepada peserta didik, pemisahan antara mata pelajaran tidak begitu nyata dan jelas, menyajikan suatu konsep dari berbagai mata pelajaran, bersifat fleksibel, hasil pembelajaran dapat berkembang sesuai dengan minat dan kebutuhan peserta didik, dan menggunakan prinsip belajar sambil bermain dan menyenangkan". ${ }^{9}$

Proses pembelajaran yang dilakukan harus menempatkan peserta didik sebaga pusat aktivitas dan harus mampu memperkaya pengalaman belajar. Pengalaman belajar tersebut dituangkan dalam kegiatan yang menggali dan mengembangkan fenomena alam yang terjadi di sekitar lingkungan peserta didik. Agar

7 Abd.Kadir dan Hanun Asrohah. (2014). Pembelajaran Tematik, Jakarta: Raja Grapindo Persada, hal. 6

${ }^{8}$ Sutirjodan Sri Istuti Mamik. (2005). Tematik, Cet. I; Malang: Bayumedia Publishing, hal. 6

9 SB, Mamat.( 2005). Pedoman Pelaksanaan Pembelajaran Tematik, Jakarta: Departemen Agama RI, hal.4

10 Abdul Majid. (2014). Pembelajaran Tematik Terpadu. Bandung: Remaja Rosdakarya, hal.92 pembelajaran yang dilaksanakan lebih bermakna maka peserta didik perlu belajar secara langsung dan mengalami sendiri, atas dasar inilah maka guru perlu menciptakan kondisi kelas yang kondusif dan memfasilitasi tumbuhnya pengalaman yang bermakna dan sebagai dasar dalam memahami hal-hal yag lebih abstrak. Pembelajaran tematik memiliki 4 karakteristik, yaitu :10 Holistik, bermakna, autentik, dan aktif.

\section{Pendidikan Agama Islam}

Pendidikan Agama Islam adalah upaya sadar dan terencana dalam menyiapkan peserta didik untuk mengenal, memahami, menghayati hingga mengimani, bertaqwa, dan berakhlak mulia dalam mengamalkan ajaran agama Islam dari sumber utamanya kitab suci al-Qur'an dan Hadits, melalui kegiatan bimbingan, pengajaran, latihan, serta penggunaan pengalaman. ${ }^{11}$

Pembelajaran Pendidikan Agama Islam adalah konsep atau desain yang digunakan pada suatu proses pembelajaran yang bertujuan untuk membantu siswa dalam belajar agama Islam. ${ }^{12}$

Pendidikan Agama Islam merupakan kegiatan yang bertujuan untuk membentuk manusia agamis dengan menanamkan aqidah keimanan dan akhlak terpuji guna menjadi manusia yang taqwa kepada Allah Swt. Serta Pendidikan Agama Islam adalah usaha-usaha secara sistematis dan pragmatis dalam membantu peserta didik supaya mereka hidup sesuai dengan ajaran Islam. ${ }^{13}$

Cakupan mata pelajaran Agama dan Akhlak Mulia dalam lampiran Peraturan Menteri Pendidikan Nasional No. 22 Tahun 2006, dimaksudkan membentuk peserta didik menjadi manusia yang beriman dan

11 Departemen Pendidikan Nasional, 2003, Kurikulum 2004: Standar KompetensiMata Pelajaran Pendidikan Agama Islam Sekolah Dasar dan Madrasah Ibtidaiyah, Jakarta.

12 Mukhtar, 2003, Desain Pembelajaran Pendidikan Agama Islam, CV. Misaka Galiza, Jakarta., hal.13

13 Usman, M. Basyiruddin, 2002, Metodologi Pembelajaran Agama Islam, Ciputat Pers, Jakarta, hal. 45 
bertakwa kepada Tuhan Yang Maha Esa serta berakhlak mulia. ${ }^{14}$

Berikut merupakan Struktur

Kurikulum Satuan Pendidikan Khusus dalam Peraturan Menteri Pendidikan Nasional No.

22 Tahun 2006.

1. Proporsi muatan isi kurikulum satuan pendidikan SMPLB A, B, D,E terdiri atas 60\%-70\% aspek akademik dan 40\%-30\% berisi aspek keterampilan vokasional. ${ }^{15}$

2. Jumlah jam pembelajaran SMPLB A, B, D, E kelas VII, VIII, IX adalah 34 jam per minggu. Kelebihan 2 jam pembelajaran dari SMP umum karena adanya penambahan mata pelajaran progam khusus. ${ }^{16}$

3. Muatan isi mata pelajaran SMPLB A, B, D, E bidang akademik mengalami modifikasi dan penyesuaian dari SMP umum sehingga menjadi sekitar 60\%-70\%. Sehingga sisanya sekitar 40\%-30\% muatan isi kurikulum ditekankan pada bidang keterampilan vokasional. ${ }^{17}$

Tujuan khusus Pendidikan Agama Islam adalah tujuan pendidikan agama Islam pada setiap tahap atau tingkat yang dilalui. Tujuan khusus Pendidikan Agama Islam untuk jenjang SLTP, yaitu memberikan ilmu pengetahuan Agama Islam, memberikan pengertian tentang agama Islam berdasarkan tingkat kecerdasannya, memupuk jiwa agama Islam, dan membimbing peserta didik supaya mereka beramal shaleh dan berakhlak mulia. ${ }^{18}$

\section{Anak Tunagrahita}

Anak Berkebutuhan Khusus adalah pengganti istilah anak berkebutuhan cacat atau penyandang cacat. Anak Berkebutuhan Khusus adalah untuk menunjuk mereka yang memiliki kelainan fisik, emosional, mental, intelektual dan sosial. Anak Berkebutuhan

14 Peraturan Menteri Pendidikan Nasional No. 22 Tahun 2006

15 Anggota IKAPI Perpustakaan Nasional, 2010, Himpunan Perundang - Undangan RI Tentang Sistem Pendidikan Nasional (SISDIKNAS): Undang - Undang RI No. 20 Tahun 2003 Beserta Penjelasannya, Nuansa Aulia, Bandung., Hal. 226

16 Ibid., hal. 227

17 Ibid., hal. 227

18 Zuhairini, H, Abdul Ghofir, \& Slamet As Yusuf, 1983, Methodik Khusus Pendidikan Agama, Biro Ilmiah
Khusus memiliki masalah dalam sensosri, motorik, belajar dan tingkahlakunya. Semua ini megakibatkan terganggunya perkembangan fisik anak. Hal ini karena sebagian besar Anak Berkebutuhan Khusus mengalami hambatan dalam merespon rangsangan yang diberikan lingkungan untuk melakukan gerak, meniru gerak dan bahkan ada yang memang fisiknya terganggu sehinggga ia dapat melakukan gerakan yang terarah dengan benar.

Efendi mengatakan tentang Anak berkebutuhan khusus yakni :

"Anak yang memiki kelainan atau penyimpangan dari rata-rata anak normal, dalam aspek fisik, mental dan sosial. Sehingga untuk mengembangkan potensinya perlu layanan pendidikan khusus sesuai dengan karakteristiknya". 19

Tunagrahita merupakan kata lain dari retardasi mental. Tuna berarti merugi, grahita artinya pikiran. Retardasi mental artinya terbelakang mental. Tunagrahita adalah keterbatasan substansial dalam memfungsikan diri. Keterbatasan ini ditandai dengan keterbatasan fungsi kecerdasan yang terletak di bawah rata-rata. Tunagrahita adalah anak yang secara nyata mengalami hambatan dan keterbelakangan perkembangan mental intelektual. ${ }^{20}$

Anak-anak dalam kelompok di bawah normal atau lebih lamban dari anak normal, baik perkembangan sosial maupun kecerdasannya disebut dengan anak keterbelakangan mental atau tunagrahita. Kecerdasan di bawah rata-rata pada seseorang maksudnya adalah apabila perkembangan umur kecerdasan seseorang terbelakang atau di bawah pertumbuhan usianya. Seseorang apabila IQ nya di bawah rata-rata atau 70 ke bawah baru dikategorikan tunagrahita.

Fakultas Fakultas Tarbiyah IAIN Sunan Ampel Malang, Malang,hal.27

19 Efendi, Mohammad, (2005). Pengantar Psikopedagogik Anak Berkelainan, Jakarta: Bumi Aksara, hal 43.

20 Umar Djani Martasuta, "Mengenal Peserta Didik yang Mengalami Gangguan

Mental", Makalah Seminar, (Jakarta: UNJ, 2001), 
Dari beberapa pendapat para ahli peneliti dapat menyimpulkan bahwa karakteristik anak tunagrahita antara lain: Waktu yang lebih lama dibanding anak pada umunya, Ketelatenan dan kesabaran guru untuk tidak terlalu cepet dalam, memberikan penjelasan, Memperbanyak latihan dari pada hapalan dan pemahaman serta Menuntut digunakannya media pembelajaran yang variatif oleh guru.

Ada berbagai cara pandang dalam mengklasifikasikan anak tunagrahita. Pengklasifikasian tunagrahita ini akan memudahkan guru dalam penyusunan program layanan pendidikan/pembelajaran yang akan diberikan secara tepat. Mengklasifikasikan tunagrahita dilihat dari berbagai pandangan, yaitu: klasfikasi berpandangan medis, pendidikan, sosiologis. ${ }^{21}$

Pengklasifikasian anak tunagrahita berpandangan pendidikan adalah mengklasifikasikan anak tunagrahita berdasarkan kemampuannya dalam mengikuti pendidikan atau bimbingan. Pengelompokan berdasarkan klasifikasi tersebut, adalah tunagrahita mampu didik, mampu latih, dan perlu rawat. Pengklasifikasian tersebut dapat dikaji sebagai berikut:22 1) Mampu didik, tunagrahita yang masuk dalam penggolongan mampu didik ini setingkat mild, borderline, marginally dependent, moron, dan debil. IQ mereka berkisa 50/55-70/75. 2) Mampu latih, kemampuan tunagrahita pada golongan ini setara dengan moderate, semi dependent, imbesil, dan memiliki tingkat kecerdasan IQ berkisar 20/25-50/55. 3) Perlu rawat, yang termasuk dalam penggolongan perlu rawat adalah anak yang termasuk totally dependent or profoundly mentally retarded, severe, idiot, dan tingkat kecerdasannya 0/5-20/25.

Pengklasifikasian anak tunagrahita berdasarkan keperluan dalam pembelajaran adalah sebagai berikut: ${ }^{23}$ 1) Educable, anak dalam kelompok ini memiliki kemapuan akademik setara dengan anak pada kelas 5

21 Mumpuniarti. (2007). Pembelajaran Akademik Bagi Tunagrahita. Buku Pegangan Kuliah Jurusan PLB-FIP-UNY. Yogyakarta: FIP-UNY,hal 13-17 22 Ibid., hal 15
Sekolah Dasar. 2) Trainable, penyandang tunagrahita dalam kelompok ini masih mampu dalam mengurus dirinya sendiri dan mempertahankan diri. Dalam mendapatkan pendidikan dan penyesuaian dalam lingkungan sosial dapat diberikan walau sangat terbatas. 3) Custodia, pembelajaran dapat diberikan secara terus menerus dan khusus. Tunagrahita dalam kelompok ini dapat diajarkan bagaimana cara menolong dirinya sendiri dan mengembangkan kemampuan yang lebih bersifat komunikatif.

Sedangkan penggolongan atau klasifikasi tunagrahita untuk keperluan pembelajaran menurut B3PTKSM adalah sebagai berikut: 24 1) taraf perbatas (borderline) dalam pendidikan disebut sebagai lamban belajar atau slow learner dengan IQ 70-85, 2) tunagrahita mampu didik (educabie mentally retarded) memiliki IQ 50-70 atau 75, 3) tunagrahita mampu latih (trainabie mentally retarded) memiliki IQ 3050 atau $35-55,4)$ tunagrahita butuh rawat (dependent or protoundly mentally retarded) memiliki IQ dibawah 25 atau 30.

Klasifikasi retardasi mental adalah sebagai berikut: ${ }^{25}$ 1) Mild retardation (IQ 5070). Secara fisik tidak nampak seperti seorang dengan ketunagrahitaan. Dapat diajarkan keterampilan-keterampilan praktis, dapat juga membaca dan menulis tapi hanya sampai pada level kelas 6 Sekolah Dasar. Selain itu, mampu dibimbing untuk melakukan penyesuaian sosial. 2) Moderate (IQ 36-50). Kemampuan gerak, khususnya berbicara nampak lambat. Dapat dilatih pekerjaan-pekerjaan sederhana, seperti latihan merawat diri. 3) Severe Retardation (IQ 20-36). Perkembangan motorik lambat, kemampuan komunikasi rendah. Dapat dilatih keterampilan dasar sseperti menolong diri, membutuhkan pengawasan dan petunjuk dalam lingkungan yang aman. 4) Profound retardation (IQ dibawah 20). Lemah dalam semua aspek perkembangan. membutuhkan pengawasan yang ketat, tidak

23 Nunung Apriyanto. (2012). Seluk Beluk Tunagrahita \& Strategi Pembelajarannya. Yogyakarta: Javalitera, hal.31-32

24 Ibid., hal. 32

25 Sugihartono dkk. (2007). Psikologi Pendidikan. Yogyakarta: UNY Press, hal. 45 
dapat merawat diri ataupun melakukan pertolongan diri sendiri.

Selanjutnya adalah sistem pengklasifikasian tunagrahita berpandangan sosiologis. Pengelompokan ini berdasarkan atas kemampuan penyandang tunagrahita dalam kemampuannya untuk mandiri di masyarakat atau apa yang dapat dilakukannya dimasyarakat. Diklasifikasikan sebagai tunagrahita ringan, tunagrahita sedang, tunagrahita berat dan sangat berat. ${ }^{26}$ 1) Tunagrahita ringan, tingkat kecerdasan $I Q$ mereka berkisar 50-70, lebih mudah dalam hal penyesuaian sosial maupun bergaul dengan orang normal yang lain, mampu menyesuaikan diri pada lingkungan sosial yang lebih luas dan mampu melakukan pekerjaan setingkat semi terampil. 2) Tunagrahita sedang, tingkat IQ mereka berkisar antara 30-50, mampu mengurus dirinya sendiri, dapat beradaptasi dengan lingkungan terdekat, dapat melakukan pekerjaan yang dilkukan secara terus menerus tapi tetap memerlukan pengawasan. 3) Tunagrahita berat dan sangat berat, tingkat kecerdasan IQ pada tunagrahita ini dibawah 30. Sepanjang hidup mereka bergantung pada orang lain. Mereka hanya dapat berkomunikasi secara sederhana dan dalam batasan tertentu.

Berdasarkan pengklasifikasian yang telah dikemukakan oleh para ahli, penulis menyimpulkan bahwa tunagrahita dapat diklasifikasikan menjadi beberapa jenis, tergantung dari sudut pandangnya. Sejalan dengan penelitian yang penulis lakukan, penulis membatasi pengklasifikasian tunagrahita berdasarkan pada kemampuan dalam menerima pendidikan atau kemapuan dalam menerima pelajaran, yakni: tunagrahita mampu didik atau tunagrahita ringan (debil), tunagrahita mampu latih atau tunagrahita sedang (imbecil), tunagrahita mampu rawat atau tunagrahita berat dan sangat berat (idiot).

\begin{tabular}{lcr}
\multicolumn{4}{c}{ Hambatan intelektual dan kesulitan } \\
dalam penyesuaian perilaku & pada \\
tunagrahita & sangat berpangaruh & dalam \\
aspek-aspek & kehidupannyayang & lain,
\end{tabular}

26 Mumpuniarti. (2007). Pembelajaran Akademik Bagi Tunagrahita. Buku Pegangan Kuliah Jurusan PLB-FIP-UNY. Yogyakarta: FIP-UNY,hal 15 sehingga mereka sering merasa kesulitan dalam mengahadapi hidupnya. Kesulitan yang dialami tunagrahita antara lain:

Kegiatan belajar mengajar adalah kegiatan yang berkaitan langsung dengan kemampuan intelegensi. Anak yang memiliki kemampuan kecerdasan dibawah rata-rata normal atau tunagrahita, menunjukkan kecerdasan rendah pada fungsi umum kecerdasannya.". ${ }^{27}$ Hal yang dianggap umum dan menjadi sesuatu yang wajar dapat menjadi luar biasa, unik, atau aneh bagi anak tunagrahita, ini dikarenakan rendahnya fungsi kogniti yang dimilikinya. Siswa yang mengalami terbelakang mental mungkin mengalami kesulitan yang besar dalam mempelajari materi yang abstrak.

\section{Metode Penelitian}

Metode penelitian ini menggukan pendekatan penelitian kualitatif. Dengan metode penggalian data pertama, Penelitian ini menggunakan pendekatan kualitatif, sementara penggalian datanya diimput dengan metode obervasi, interview, dan dokumentasi. Sedangkan analisis datanya menggunakan analisis kualitatif dari Miles dan Hubberman, yaitu dengan tiga tahapan, yakni 1) reduksi data (data reduction), 2) penyajian data (data displays dan 3) penarikan kesimpulan/ verifikasi (conclusion drawing/veriffication).

\section{Hasil Penelitian}

\section{Pelaksanaan metode tematik dalam pembelajaran PAI pada siswa tunagrahita di SMPLB Ngasem kabupaten Kediri.}

Dari pengamatan peneliti dalam menyampaikan materi, baik materi yang disampaikan berbeda maupun sama, guru tetap memperhatikan perbedaan kebutuhan yang dimiliki tiap siswa SMPLB (sekolah menengah pertama luar biasa) dengan memberikan materi yang disesuaikan dengan kemampuan dari tiap siswa SMPLB (sekolah menengah pertama luar biasa) Ngasem.

Materi pelajaran dengan lingkungan siswa sudah saling berkaitan. Guru selalu bertanya dahulu pada siswa tentang

27 Mohammad Efendi. (2006). Pengantar Psikopedagogik Anak Berkelainan. Jakarta: PT Bumi Aksara, hal. 96 
pengalaman yang pernah dialami, lalu dari pengalaman siswa tersebut, guru menghubungkannya pada materi pelajaran yang sesuai dengan pengalaman siswa tersebut. Kegiatan pembelajaran berada di dalam kelas agar siswa dapat fokus dan tidak bermain-main di luar kelas.

Didalam kelas secara garis besar pembelajaran sudah berpusat pada siswa. Hal itu dapat dilihat saat guru selesai memberikan kesempatan pada siswa untuk menyampaikan pendapatnya yang masih dalam ruang lingkup materi yang sedang dipelajari.

Pertimbangan dengan menggunakan hasil asesmen dikemukakan pula oleh Marthan yakni, "Terlaksananya proses pembelajaran yang ramah bagi ABK (anak berkebutuhan khusus) harus didasari pada pelaksanaan observasi dan asesmen yang terencana". ${ }^{28}$ Hasil assesmen siswa SMPLB (sekolah menengah pertama luar biasa) Ngasem rata -rata menunjukkan bahwa kemampuan kognitifnya setara dengan kategori tunagrahita sedang, sehingga guru menyampaikan materi siswa SMPLB (sekolah menengah pertama luar biasa). Pelaksanaan kegiatan pembelajaran tematik dapat digambarkan dari hasil observasi dan wawancara. Metode pembelajaran tematik yang berfokus pada pembelajaran pendidikan agama islam dalam pemahaman agama sangat baik dan anak - anak juga bisa menikmati proses pembelajaran dan tidak merasa kesulitan dalam memahami materi yang disampaikan oleh guru.

Dari hasil pengamatan peneliti guru agama di Sekolah Menengah Pertama Luar Biasa (SMPLB) Ngasem mampu menciptakan suasana kelas yang kondusif, demokratis, tidak tegang, dan tertib agar semua siswa dapat fokus dalam menyimak, berbicara, dan mengekspresikan diri. Menciptakan kondisi kelas yang ideal bukanlah hal yang mudah. Bahkan seringkali kondisi kelas menjadi kaku, tegang, dan menakutkan sehingga siswa takut untuk menyampaikan pendapat dan mengekspresikan diri, meski terkadang juga suasana kelas terlalu bebas dan rebut

28 Mumpuniarti. (2007). Pembelajaran Akademik Bagi Tunagrahita. Buku Pegangan Kuliah Jurusan PLB-FIP-UNY. Yogyakarta: FIP-UNY, hal. 155 yang mengakibatkan siswa sulit untuk konsentrasi.

Pembelajaran tematik perlu memanfaatkan berbagai sumber belajar baik yang sifatnya didesain secara khusus untuk keperluan pelaksanaan pembelajaran, maupun sumber belajar yang tersedia di lingkungan yang dapat dimanfaatkan. ${ }^{29}$

Pada kegiatan pembelajaran di SMPLB (sekolah menengah pertama luar biasa) Ngasem, guru telah menggunakan beberapa sumber belajar buku. Guru juga terkadang menggunakan lingkungan sebagai sumber belajar siswa agar lebih paham.

Berdasarkan observasi yang dilaksanakan, pembelajaran di SMPLB (sekolah menengah pertama luar biasa) Ngasem pelaksanaan kegiatan pembelajaran belum sesuai dengan perencanaan pembelajaran. Pada umumnya, pembelajaran belum sepenuhnya terlaksana seperti langkah-langkah kegiatan yang tertulis di RPP (rencana pelaksanaan pembelajaran). Tujuan pembelajaran belum berhasil secara keseluruhan karena hasil belajar siswa belum mencapai tujuan pembelajaran yang diharapkan.

Peneliti menemukan bahwa proses pembelajaran tematik diterapkan agar peserta didik mampu menguasai dan memahami materi dengan baik sehingga peserta didik yang tidak tuntas belajar dapat menjadi tuntas belajar, dan yang telah tuntas belajar dapat lebih ditingkatkan kembali. Upaya peningkatan kualitas pembelajaran yang dilakukan guru dalam berbagai cara, diantaranya meningkatkan aktivitas guru dalam membimbing peserta didik. Guru lebih intensif untuk membimbing peserta didik dalam memahami pelajaran agama.

Sejalan dengan penyataan tenaga pendidik melalui wawancara yang mengatakan bahwa :

"Guru dalam meningkatkan kualitas pembelajaran dikelas, upaya yang dilakukan diantaranya meningkatkan aktivitas dalam membimbing peserta didik, lebih intensif untuk membimbing peserta didik dalam

29 Abdul Majid. (2014). Pembelajaran Tematik Terpadu. Bandung: Remaja Rosdakarya, hal.190 
memahami materi terutama pelajaran agama islam". 30

Didalam proses pembelajaran dengan menggunakan metode tematik ini ada beberapa faktor yang juga mempengaruhi keefektifan proses belajar siswa terbelakang diantaranya ; 1) Siswa terbelakang mental mendapatkan kesulitan dalam memfokuskan perhatian mereka pada sebuah tugas dalam waktu yang lama. 2) Siswa terbelakang mental mendapat kesulitan mengenal dan berfokus pada aspek-aspek tugas yang penting. 3) Siswa terbelakang mental mendapat kesulitan dalam memindahkan dan menyamaratakan kemampuan dari satu konteks ke konteks lainnya. 4) Siswa terbelakang mental sulit mendapat keterangan dengan mudah yang berhubungan dengan masalah yang utama, mungkin mereka ketinggalan memahami arti bacaan atau pelajaran. 5) Siswa terbelakang mental dapat melupakan informasi dengan sangat cepat dibanding yang lain.

Guru juga mengaitkan pembelajaran dengan persoalan sehari-hari, Guru menggunakan contoh disekitar yang mudah untuk ditemui siswa. "baju yang dicuci ibu dijemur biar apa?", "biar kering". Atau Guru memberikan penjelasan tentang perbuatan jujur dan tidak jujur dengan cara yang mudah diapahami dan familiar dengan siswa. Guru memberikan contoh dengan menceritakan membeli jajan di kantin sekolah dan membayar dengan uang yang tidak sesuai. Ini akan memudahkan siswa karena dia mengalami hal tersebut (jajan di kantin sekolah) hampir setiap hari.

Dalam pembelajaran bagi tunagrahita, selain prinsip umum pembelajaran, terdapat pula prinsip khusus pembelajaran bagi tunagrahita. Pertama, prinsip kasih sayang, disetiap pembelajaran guru selalu melaksanakan prinsip kasih sayang. Guru dalam menyampaikan materi dengan penuh kesabaran. Guru juga tidak segan-segan untuk menjelaskan kembali materi dari awal, bila ada siswa dirasa belum mengerti. Bila siswa mengalami kesulitan, guru akan membimbing dengan penuh kesabaran. Bahwa anak tunagrahita jika

30 Wawancara dengan guru pai, pada tanggal 31 juli 2018 di kelas. dihadapkan pada persoalan yang membutuhkan proses pemanggilan kembali pengalaman atau peristiwa yang lalu sering mengalami kesulitan. Sehingga materi diberikan secara berulang-ulang. Dalam memberikan bimbingan atau pendampingan, guru tidak pernah menunjukkan raut muka yang tidak menyenangkan seperti cemberut. Guru sering tersenyum dalam memberikan bimbingan pada anak tunagrahita.

Pernyataan diatas ditegaskan oleh bu Vita, selaku guru pendidikan agama islam, menegaskan sebagai berikut :

Model pembelajaran sangatlah penting, dan tidak kalah penting adalah bagaiamana perilaku atau sikap dari guru itu sendiri, yang pertama harus sering-sering mengulang pelajaran lewat jam pelajaran maupun perbuatan kebiasaan. Guru juga harus selalu tersenyum dihadapan siswa dan tidak boleh memperlihatkan rasa esmosinya atau apapun yang mengakibatkan siswa tidak tertarik kepada gurunya. ${ }^{31}$

Berdasarkan analisa peneliti dapat disimpulkan bahwa dalam pembelajaran tematik relatif baik guru yang mengajar kreatif dan inovatif dalam mempersiapkan kegiatan pembelajaran, mampu menghadapi berbagai macam karakter siswa, dan mampu mengaturnya pembelajaran menjadi lebih bermakna, menarik, aktif dan menyenangkan. Guru juga sudah mampu menciptakan suasana kelas yang kondusif, demokratis, tidak tegang, dan tertib agar semua siswa dapat fokus dalam menyimak, berbicara, dan mengekspresikan diri.

\section{Hasil pembelajaran Tematik dalam Pelajaran Pendidikan Agama Islam}

Tercapainya ketuntasan metode pembelajaran tematik tidak lepas dari beberapa aspek yang menunjang dalam proses pembelajaran. Aspek-aspek tersebut antara lain: aktivitas guru dalam menyajikan pembelajaran tematik, aktivitas peserta didik dalam mengikuti kegiatan pembelajaran. Peranan guru dalam menyajikan suatu pembelajaran sangatlah penting. Guru sebagai perencana sekaligus pelaksana harus mampu menciptakan situasi pembelajaran

31 Wawancara dengan guru pendidikan agama, bu vita farida m. Di kelas, 31 juli 2018. 
yang menyenangkan bagi peserta didik, memotivasi dan mengarahkan peserta didik kedalam kegiatan belajar mengajar sesuai apa yang telah disusun dalam sebuah rencana pelaksanaan pembelajaran. Kemampuan guru dalam membimbing peserta didik dimana guru dituntut untuk dapat mengidentifikasi kesulitan yang dialami peserta didik ketika proses pembelajaran sedang berlangsung. Kemampuan guru dalam menyajikan pembelajaran memberikan pengaruh dalam keberhasilan proses pembelajaran.

Pembelajaran tematik di SMPLB (sekolah menengah pertama luar biasa) Ngasem yang diterapkan pada anak tunagrahita yakni tingkat sekolah menengah pertama luar biasa berada dalam tingkat kategori baik. cukup menunjang dan mendukung sehingga peserta didik dapat meningkatkan belajar tematik dengan tema yang diajarkan. Peserta didik dihadapkan pada sesuatu yang nyata sebagai dasar untuk memahami hal-hal yang lebih abstrak. Agar pembelajaran lebih bermakna maka peserta didik perlu belajar secara langsung dan mengalami sendiri. Atas dasar ini maka guru perlu menciptakan kondisi yang kondusif dan memfasilitasi tumbuhnya pengalaman yang bermakna. ${ }^{32}$

Dengan demikian, peneliti dapat menyimpulkan bahwa media pembelajaran sangat membantu siswa menjadi lebih aktif melakukan beragam aktivitas, pembelajaran lebih menarik, dan bahan yang disajikan menjadi lebih jelas maknanya bagi peserta didik sehingga dapat dipahami dengan jelas. Media membuat peserta didik diajak lebih antusias dalam memperhatikan guru menyampaikan materi sebab peserta diajak melihat langsung benda atau contoh-contoh yang sesuai dengan materi pembelajaran. Sehingga penggunaan alat dan media sangat dibutuhkan dalam media pembelajaran.

Ada berbagai cara pandang dalam mengklasifikasikan anak tunagrahita. Pengklasifikasian tunagrahita ini akan

32 M. Maftuhin and A. Jauhar Fuad, "Pembelajaran Pendidikan Agama Islam Pada Anak Berkebutuhan Khusus," Journal An-Nafs: Kajian Penelitian Psikologi 3, no. 1 (June 24, 2018): 83-98-8398 memudahkan guru dalam penyusunan program layanan pendidikan/pembelajaran yang akan diberikan secara tepat. Mengklasifikasikan tunagrahita dilihat dari berbagai pandangan, yaitu: klasfikasi berpandangan medis, pendidikan, sosiologis. 33

Metode pembelajaran tematik dapat dikatakan berhasil karena sesuai dengan prosedur yang ada.Dalam pengamatan dan wawancara peneliti kepada peserta didik serta guru. Hasil wawancara serta pengamatan menunjukkan bahwa metode pembelajaran tematik ini memberikan beberapa manfaat yang membantu peserta didik dalam pemahaman pendidikan agama islam, antara lain sebagai berikut. 1) Melatih peserta didik berpikir sintesis, aktif, dan kritis. Bila dilihat dari pengamatan dan wawancara yang terkait dengan hal tersebut, hampir semua peserta didik menyatakan bahwa mereka dengan metode pembelajaran tematik dalam pemahaman agama dapat berpikir sintesis, aktif dan kritis. 2) Peserta Didik lebih termotivasi dengan adanya metode pembelajaran tematik. 3) Peserta didik lebih mudah memahamim pelajaran dan merasa senang dengan menggunakan metode tematik, hal tersebut terlihat ketika proses belajar mengajar anak- anak lebih memerhatikan dan aktif.

Dari hasil penelitian pada saat proses pembelajaran ada anak tunagrahita sering mengalami gangguan emosi dan masalahmasalah perkembangan emosi sehubungan dengan kemampuannya yang rendah. Perilaku emosi yang sering dinampakkan seperti agresif, baik verbal maupun performance, marah (kadang meledakledak), takut, cemas, dingin, impulsif, lancang dan merusak. Hal ini sesuai dengan pernyataan dari Bu Vita, selaku guru agama di Sekolah Menengah Pertama Luar Biasa Ngasem yakni :

"Anak berkebutuhan khusus biasanya dalam proses belajar mengajar membutuhkan mood, jadi kalau mood anak

33 Mumpuniarti. (2007). Pembelajaran Akademik Bagi Tunagrahita. Buku Pegangan Kuliah Jurusan PLB-FIP-UNY. Yogyakarta: FIP-UNY,hal 13-17 
tidak terkendali maka pasti dalam proses belajar mengajar tidak bisa maksimal contohnya anak bisa esmosi dengan masalah sepele, sensitif terhadap tindakan dan biasaya kalau sudah esmosi suka tidak terkontrol/ meledak-ledak". ${ }^{34}$

Peneliti menarik kesimplan bahwa pembelajaran tematik lebih banyak berpusat pada siswa agar potensi mereka dapat berkembang, serta pembelajaran tematik perlu dilakukan dengan metode-metode yang bervariasi agar siswa tidak bosan.

\section{Kesimpulan}

Dari pembahasan bab demi bab tentang implementasi pembelajaran tematik dalam pelajaran pendidikan agama Islam di SMPLB (sekolah menengah pertama luar biasa) Ngasem Kabupaten Kediri serta berdasarkan temuan dan pembahasan, maka pada bagian penutup dapatlah ditarik kesimpulan sebagai berikut :

Implementasi pembelajaran tematik di SMPLB Ngasem relatif baik dan dapat membantu mempermudah peserta didik dalam memahami pelajaran khususnya pendidikan agama Islam. Pembelajaran tematik ini berorientasi pada kecakapan peserta didik memproses informasi mengacu pada cara-cara orang menangani stimuli dari lingkungan, mengorganisasikan data, melihat masalah, mengembangkan konsep dan memecahkan masalah.

Dari hasil penelitian dengan menggunakan model pembelajaran tematik mereka lebih semangat dan antusias mendengarkan dan memikirkan pemecahan masalah yang sedang dibahas, dengan model pembelajaran seperti ini juga membangkitkan rasa tanggung jawab, kemandirian, jiwa sosial serta membuat mereka tidak begitu susah dalam pemahaman pelajaran yang sedang berlangsung.

\section{Daftar Pustaka}

agama bu vita farida m. Di kelas, 31 juli 2018
Abdul Majid. (2014). Pembelajaran Tematik Terpadu. Bandung: Remaja Rosdakarya.

Abd Kadir dan Hanun Asrohah. (2014). Pembelajaran Tematik. Jakarta: Rajawali Pers

Anshori, Muchafid. 2012. Pendidikan Agama Islam Adaptif di Sekolah Luar Biasa. Jakarta: Pustikom

Desmita. (2012). Psikologi Perkembangan Peserta Didik. Bandung: Remaja Rosdakarya.

Dimyati dan Mudjiono. Belajar dan Pembelajaran. Jakarta: Rineka Cipta, 2006.

Miles dan Huberman. Analisis Data Kualitatif. 1992. Buku Sumber Tentang Metode-metode Baru. Jakarta : Universitas Indonesia Press.

M. Maftuhin and A. Jauhar Fuad, "Pembelajaran Pendidikan Agama Islam Pada Anak Berkebutuhan Khusus," Journal An-Nafs: Kajian Penelitian Psikologi 3, no. 1 (June 24, 2018): 83-98-83-98

Muchith, M. Saekhan. 2008. Pembelajaran Konstekstual. Semarang: Rasail media Group. Cet. 1.

Moleong, Lexy J. 2004. Metodologi Penelitian Kualitatif. Bandung: Remaja Rosda karya.

Mulyasa, E. 2005. Menjadi Guru Profesional: Menciptakan Pembelajaran Kreatif dan Menyenangkan. Bandung: PT Remaja Rodaskarya.

Nasih, Ahmad Munjir dan Kholidah, Lilik Nur. 2009. Metode dan Teknik Pembelajaran Pendidikan Agama Islam. Bandung: PT. Refika Aditama.

Sanjaya, Wina. 2009. Strategi Pembelajaran Berorientasi Standar Proses 


\section{intëlëktuãl}

Jurnal Pendidikan dan Studi Keislaman
Implementasi Metode Tematik...

Oleh : Ubed Nasrul Kamal \& Syafik Ubaidila

Pendidikan. Jakarta: Kencana Prenada Media Group.

Sisdiknas, 2009. Jakarta: Sinar Grafika.

Sutopo. 2002. Metodologi Penelitian Kualitatif Dasar Teori dan Terapannya dalam Penelitian. Surakarta: Uiversitas Sebelas Maret Press.

Trianto. (2011). Desain Pengembangan Pembelajaran Tematik bagi Anak Usia Dini TK/RA \& Anak Usia Kelas Awal SD/MI. Jakarta: Kencana.

Uhbiyati, Nur. Ilmu Pendidikan Islam (IPI): untuk Fakultas Tarbiyah Komponen PMDK. Bandung: Pustaka Setia, 1998. cet-ke 2.

DPR RI, 2013. Undang-Undang Republik Indonesia Nomor 20 Tahun 2003. 2013 Bandung: Citra Umbara. 